\title{
New Social Movements: "Refugees Welcome UK”
}

\author{
Burcu Togral Koca, PhD \\ Eskisehir Osmangazi University/Turkey
}

doi: 10.19044/esj.2016.v12n2p96 URL:http://dx.doi.org/10.19044/esj.2016.v12n2p96

\begin{abstract}
This study addresses the dynamics of new social movements with a special emphasis on the "Refugees Welcome UK" in the light of the Syrian refugee crisis. Since March 2011, over four millions of people have fled civil war in Syria and sought refuge mainly in neighbouring countries, such as Turkey, Jordan, Egypt and Lebanon. However, precarious living circumstances and uncertain legal status in these countries have forced hundreds of thousands of Syrians to head for Europe in quest for a better life. The European countries, on the other hand, have adopted restrictive approaches towards Syrian refugees. Among these European countries, the UK has been the most criticized one because of its indifference to the plight of Syrian refugees. Under the leadership of David Cameron, the UK has taken a restrictive stance on accepting Syrian refugees and resisted any solution attempts at the EU level. Contrary to this anti-refugee approach at the state level, there emerged social movements in support of refugees throughout the UK. The most prominent one is the "Refugees Welcome" movement engaging in various strategies, ranging from seeking donation to raising public awareness. Building upon the insights of "New Social Movements" paradigm and using documentary analysis, this article explores the dynamics of this movement, its demands and objectives, social base, organizational structure, mobilization strategies and medium of action and social location. The article seeks to contribute both to the literature on social movements and to the current debate on refugees.
\end{abstract}

Keywords: New Social Movements, Refuge Rights Movements, the UK, Syrian Refugee Crisis

\section{Introduction}

"A specter haunts the world and it is the specter of migration."

(Hardt and Negri, 2002, p.213)

According to the United Nations (UN) "the civil war in Syria resulted in the worst refugee crisis in the last two decades" (Güçtürk, 2014, pp. 7879). Since the war erupted in 2011, over four million Syrians have fled their 
home due to the civil war and have sought refuge mainly in the neighbouring countries, such as Turkey, Jordan, Egypt, and Lebanon. From the very beginning of the civil war, these countries have followed an "open door" policy towards Syrian refugees. However, the rising number of Syrian refugees in these countries has raised concerns over various issues, including access to basic services such as health and education, exploitation in labor market, child labor boom, violence against children and women, and low school enrolment of the non-camp refugees. In this context, precarious living circumstances and uncertain legal status have forced hundreds of thousands of Syrians in these countries to head for Europe in quest for better life opportunities by travelling in poor quality and overcrowded boats across the Mediterranean or by dangerous land routes. The UN recorded that just in October 2015, more than 218,000 refugees crossed the Mediterranean, almost the same number as throughout 2014 (Aljazeera, 2015 November 2). In 2015 , over 744,000 people made this journey and more than 3,440 people have lost their lives or gone missing attempting to cross the Mediterranean to Europe (ibid). However, while escaping from dire conditions they face in Syria's neighbouring countries, they are left in cruel limbo by European states' anti-immigrant, draconian practices. As it is widely criticized, the European states have not shared the responsibility of this refugee crisis. Only Sweden and Germany have accepted limited number of Syrian refugees since the war started in 2011. Especially Germany took the lead with its historic decision of opening its borders to refugees stuck in Hungary (Spiegel, 2015 November 2). Berlin suspended the Dublin Protocol for Syrian refugees "by declaring all Syrian asylum-seekers welcome to remain in Germany - no matter which EU country they had first entered (Hall and Lichfield, 2015 August 25). However, recently Angela Merkel has come under intense fire for her "liberal" approach towards refugees both at home and in the EU forcing her to reinstate border controls at Austrian border and to hold talks with Turkey's President Recep Tayyip Erdogan and his Prime Minister Ahmet Davutoglu on 18 October 2015. Accordingly, Merkel has sought Turkey's help in controlling and containing Syrian refugees through increasing border controls in return for financial aid, "acceleration of EU membership talks and for concessions on liberalized visa requirements" (Arslan, October 24 2015). On the other hand, other European countries, such as Hungary and Bulgarian have further securitized and militarized their border controls through closing their borders, erecting fences, deploying border guards and other draconian surveillance measures.

Similarly, from the very beginning of the Syrian refugee crisis, the UK under the leadership of David Cameron has also followed a restrictive approach and resisted any solution attempts such as the one proposing the “distribution quotas of refugees on the basis of each country's population 
and resources” (Balibar, 2015) . Regarding this proposal, Cameron commented, "European leaders attempting to impose quotas of migrants on countries across the continent are 'encouraging' people to make 'potentially lethal’ journeys” (The Telegraph, 2015 September 4). Instead, he proposed that:

We're saying we will play our part in resettling those people who need resettling, but we'll take you from refugee camps rather than encourage people to make this dangerous, potentially lethal crossing (ibid.).

Followingly, the government offered to resettle only 20,000 refugees over five year (Bowcott, 2015 October 12), which is very limited compare to the number of refugees hosted by Syria's neighboring countries.

Contrary to this anti-refugee setting at the state level in the UK - as well as in other European countries -, there emerged social movements in support of refugees. ${ }^{7}$ Indeed, it should be noted that long before the Syrian refugee crisis, the UK has witnessed the emergence of various refugee rights movements as a response to the state's exclusionary and restrictive migration regime. For example, the Refugee Council, Amnesty International UK, Save the Children as well as other local groups among others have been actively supporting refugees and immigrants through the UK. However, the latest refugee crisis emerging out of the Syrian war has mobilized a different type of collective action that includes not only pro-refugee Non-Governmental Organizations (NGOs) and groups but also individual volunteers as well as other organizations working in different fields. The "Refugees Welcome" movement, which has counterparts across Europe, is the clearest example of this kind of collective action. With the worsening of the refugee crisis, ${ }^{8}$ this group has been set up in September 2015; since then it has organized various demonstrations, sought donations, and tried to raise public awareness on the plight of refugees. The movement is not only active throughout the UK but also in Calais (France) ${ }^{9}$ as well as in Greek islands.

\footnotetext{
${ }^{7}$ For a long time, pro-immigrant-and-refugee groups across Europe have been organized under various banners, such as "No Border" and "No one is Illegal". However, Syrian refugees have given a new impetus to these movements.

${ }^{8}$ Especially, the shocking images of a three-year-old Syrian boy, named Aylan Kurdi, who drowned early September 2015 off a beach near Turkish resort of Bodrum , have mobilized thousands of people across Europe under the banner of "Refugees Welcome".

${ }^{9}$ Calais is port city of France - called also the "jungle" - where thousands of migrants mostly from Afghanistan, Iraq, Eritrea and now from Syria, have been living in "makeshift" camps almost more than ten years (Rygiel, 2011, p.1). Recently, it is reported that: "After a tightening of security and fencing at Calais port, and around Channel tunnel train services, migrants and refugees are taking more risks in their efforts to reach the UK. Since 26 June, at least 13 people have died trying to stow away on lorries or trains to cross the Channel, with several being hit by freight trains at the tunnel entrance.” (Angelique Chrisafis, 2015).
} 
Against this backdrop, drawing on the "new social movements" (NSMs) paradigm, this study traces the dynamics of the "Refugees Welcome” movement under five headings focusing on its 1) demands/objectives; 2) social base; 3) organizational structure; 4) mobilization strategies and medium of action; and 5) social location. The empirical analysis of the study is carried out through a documentary analysis of social media sources (facebook), webpage of the movement, newspapers in addition to a review of relevant academic works. This study seeks to provide important insights into the literature both on NSMs and on refugee studies.

\section{Dynamics of the "Refugees Welcome" Movement from a NSMs Paradigm}

Over the past decades, there emerged intense academic debate over the question of "what is "new" in NSMs?" in developing an analytical framework for the conceptualization of NSMs. These discussions came on the scene particularly in Western Europe and focused on "the limits of Marxism [...] that stressed economic and class-based (rooted in the process of production) movements to the exclusion of most others” (Lise, 2003, p.13). Indeed, this "turn" in academia is also closely linked to the changing dynamics of social movements since the 1960s, "marked by new struggles and repertories of resistance, by new contexts of participation and by new forms of organizations” (Feixa et al., 2009, p. 424).

Even though scholars, such as Habermas (1981), Melucci (1980) and Touraine (1981) among others, offered the first explanatory frameworks to these debates (Slater, 1991, p. 33), ${ }^{10}$ it is still difficult to talk about a "theory" of NSMs, which necessitates "a set of general propositions that have been verified empirically" (Johnston et al., 1994, p. 6). Rather, it is much more appropriate to treat the concept of NSMs as an approach and to

\footnotetext{
10 According to Habermas, modern attacks on what he referred to as the "organic foundations of the life world" had triggered new forms of protest and action. The tangible destruction of the urban environment and of the countryside through unchecked economic growth, the detrimental effects of pollution on the health of population, and the modern obsession with material wealth were seen as key causes of the emergence of the ecological and anti-nuclear movements (Slater, 1991, p. 33). On the other hand, for Melucci, "the conflict between the agencies of social manipulation and the desire of individuals to 'reappropriate society's resources and to claim collectively the right to realize their own identity; the right of disposing of their personal creativity, their affective life and their biological and interpersonal existence'” are the driving forces behind the emergence of new social movements (ibid.). According to Touraine (1981), the historical transition from an old industrial society to a new post-industrial society, which has induced new concerns and new mobilization strategies, is the decisive factor in the emergence of new social movements.
} 
form an analytical framework by contrasting NSMs with the "conventional" ones of the "past that originated in class conflict" (ibid.). Following this stance, this study articulates an analytical framework through focusing on qualitative differences between NSMs and earlier examples of mainly classbased social movements. Toward this aim, drawing on the literature on NSMs, the study focuses on the following elements that are accepted as the most decisive ones in identifying the differences between NSMs and "conventional" social movements (ibid.; see also Scott, 1990). At the same time, the study offers an empirically grounded analysis to these discussions by exploring the "Refugees Welcome" movement in the UK.

\section{Demands and Objectives}

One of the important differences between NSMs and "conventional" movements relates to the demands and objectives of these movements. The conventional working class/labour movements, including the revolutionary wave of 1848, the Paris Commune, and other movements organized by trade unions, have prioritized "material" (economic) concerns and class interests since the industrialization in Western Europe. On the other hand, Melucci argues that NSMs focus on "cultural and symbolic issues that are linked with issues of identity" (as cited in Johnston et al., 1994, p.7). NSMs are also based on "less 'objective' elements such as [...] status, humanism, and spirituality.” (ibid., p. 21). For example, their demands and objectives concentrate on women and gay rights, environmental issues, animal rights and minority protection. Rather than seeking their own material/economic and class interests, they try to promote the rights of marginalized groups and protect the nature and environment against the destruction of capitalist economy.

Similarly, the demands and objectives of the "Refugees Welcome" movement stand in contrast to the economic or materialistic ones of the "conventional" working class movements. Based on "humanism" and "human rights" discourses, they are promoting the rights of refugees. This is clearly confirmed by the movement by stating that "offering sanctuary to those in need of refuge is a proud British tradition" (Refugees Welcome, 2015). It is further declared that the major objective of the movement is:

to bring together major civic society institutions and groups across the UK to mobilise their resources to support the government, local authorities and specialist providers in resettling 20,000 Syrian refugees by 2020 and to go further in bringing more refugees to safety in Britain” (ibid.)

Besides, some other demands and objectives of the movement detailed under the "Refugees Welcome Joint Statement" are as follows: 
1. Pressuring the UK to take a fair and proportionate share of asylum seekers and refugees, both those already within the EU and those still outside it.

2. Establishing safe and legal routes to the UK, as well as to the EU for all refugees through humanitarian visas; resettlement schemes; humane family reunion policies,

3. Ensuring appropriate funding of the existing specialist support for refugees and asylum seekers and for co-ordination of volunteer initiatives.

4. Abandon plans to introduce the new Immigration act calling for a more restrictive stance towards asylum seekers (ibid.).

On the other hand, not only "natives", but also refugees and immigrant communities are actively involving in this movement. By this way, they seek to challenge both the "sovereign control" and "traditions of the political that are centered upon the politics of visibility" (Nyers, 2015, p. 29). In particular, they support these movements

to achieve various forms of visibility: e.g. to "come out of the shadows" and into public life; to have rights and personhood recognized in law and by society; to have a political voice and say in civic and daily life; to be included, accepted, and integrated (ibid.).

In this respect, we can also assert that "the relation between the individual and the collective is blurred" (Johnson et al., 1994, p. 7). In other words, "the movement becomes the focus for the individual's definition of himself or herself, and action within the movement is a complex mix of the collective and individual confirmations of identity” (ibid., p. 8).

\section{Social Base}

Closely related to the above point, the social base and the membership profile of NSMs differ from the "conventional" social movements. Unlike the class-based structure dominating "conventional" movements such as labour unions, we can observe multi-class and heterogeneous formations in the context of NSMs. In other words, the social base of NSMs tends to "[move] away from class" (Carroll and Ratner, 1995, p. 426) and their members come from different backgrounds with diffuse social status relating to age, gender, sexual orientation, and professions ( Johnston et al., 1994, p. 6). Closely connected to this, contrary to the Marxists approach treating ideology as a unifying force for collective action, NSMs signify heterogeneity in terms of ideas and values (ibid.).

This assertation is also confirmed by the "Refugees Welcome" movement consisting of supporters/members from different backgrounds. Women and men, young and old, Muslim and Christian faith groups, "rich" and "poor" and as previously mentioned, refugees and immigrants have all 
supported the plight of refugees under "Refugees Welcome" banner. ${ }^{11}$ To be more tangible, the movement's "National Refugee Welcome Board" includes bishops, members of Liberal Judaism group, people from Syrian community, Pilgrim Church, members of Citizen UK, Vice Chancellor of University of East London, and Muslim Council of Wales in addition to the representatives from various local relief groups and intergovernmental organizations (see Refugees Welcome, 2015). Furthermore, all these groups are likely to have different "ideological" orientation ranging from liberals to conservatives. In this context, differences in their value system, status, or ideological stances do not prevent them from being unified under non-material objectives.

\section{Mobilization Strategies and Medium of Action}

Third, NSMs use "new mobilization patterns characterized by nonviolence..., while often challenging dominant norms of conduct" (Johnston et al. 1994, p. 8). Especially, communication and information technologies are employed as mobilizing instruments. In particular, social media is playing "a substantial role in creating and spreading the language of resistance" (Öğ̈̈n-Emre et al., 2014, p. 7). The Occupy Street and "Arab Spring" movements are the key examples to this tendency. They offer alternative action repertoires contrary to the ones - such as strikes and demonstrations - carried out by "conventional" movements.

The "Refugees Welcome" movement also utilizes "non-conventional" strategies to mobilize people and spread its words. Particularly through social media, including Facebook and Twitter, they have already organized massive protests and took to the streets throughout the $\mathrm{UK}^{12}$. For example, it is reported that:

In London, thousands of people - young and old, British, Syrian and other nationalities - snaked down Pall Mall and Whitehall on [12 September 2015], many carrying placards and chanting "Say it loud and say it clear: refugees are welcome here”, and pausing outside Downing Street to boo, with some shouting: "David Cameron, shame on you.” (Graham-Harrison and Davies, 2015 September 12).

Similar demonstrations took place in other cities, including Belfast, Glasgow, Cardiff, Brighton, Manchester, York, Edinburgh among others (ibid.). Again, through Facebook and Twitter, the movement has organized various campaigns and collected clothes and foods for refugees not only in the UK but also in Calais or Greek islands. Besides, through its

\footnotetext{
${ }^{11}$ See the web-page of the "Refugees Welcome" at http://www.refugees-welcome.org.uk/ and their facebookpage for a detail wiew of the profile of their members/supporters.

${ }^{12}$ In Germany, Austria, Denmark, and Hungary, thousands of people also took to the streets and organized demonstrations and campaigns under the banner "Refugee are welcome" following the mass arrivals of Syrian refugees.
} 
webpage, the movement calls for public to provide private sponsorship, housing as well as for lobbying their MPs (Refugees Welcome, 2015).

\section{Organizational Structure}

Another difference between NSMs and "conventional” movements lies in their organizational structure. Unlike the centralized, hierarchical, and formal structures of "conventional” social movements, it is widely asserted that the "new" ones have decentralized, segmented, diffuse, and informal structures consisting of voluntary members. Gunathilake (n.d) states that:

Most "old” social movements embraced the idea of leadership roles, with consensual and centralized decision making by a selected few members, while new social movements have adopted a leaderless horizontal structure by employing an organizational format they refer to as the people's assembly (p. 4).

The "Refugees Welcome" movement is also organized in a more decentralized and diffuse way without having a specific leadership. Despite the recently convened "National Refugee Welcome Board", the movement does not have a hierarchically organized institutional structure. Rather, it is formed by a network of actors, groups, and organizations. For example, there are local committees independently organizing campaigns and conducting projects. These committees work in close cooperation with local authorities, universities and other charity organizations and they offer training days for those willing to support refugees (see Refugees Welcome, 2015). More importantly, they promote "integration" of refugees through providing them with education and language training programmes. They have also established befriending and monitoring networks involving volunteers. There is, for example, "Welcome Dinner” Project “[relying] on volunteer facilitators to create successful experiences where people come together across cultures over a shared meal” (ibid.). Furthermore, there are also individual volunteers and other civil society organizations supporting the objectives of the movement by offering material and non-material support. This non-hierarchical organizational structure is likely to provide all supporters/members to engage in the movements actively and to create a platform for future volunteers.

\section{Social Location}

Lastly, there is a difference as to the social location of NSMs and "conventional" movements. Unlike the relatively "local" character of the latter, though in certain cases, having "involved in revolutionary or reform processes at the national and international levels” (Feixa et al., 2009, p. 426), the former tend to transcend national boundaries and form alliances with 
similar movements in other countries with the help of developments in communication and information technology.

When it comes to the "Refugees Welcome" movement, as foregrounded previously, it also takes actions at local, national, and transnational levels. On their Facebook page, it is stated that "'Refugees Welcome UK' aims to connect its members with people and organisations working across the Middle East and Europe to help those affected - whether it's lobbying, campaigning, feeding and clothing people, housing them or pulling them out of the sea". Towards this aim, members/supporters of the movement have already established networks and alliances in all over Europe. For example, they have organized campaigns under the CalAid initiative in Calais. This initiative has mobilized public to collect "the things [Calais refugees] most urgently need - from backpacks to shoes and candles" (Refugees Welcome, 2015). Referring to the Calais case, it is underlined that:

Because there has been limited support from major aid agencies and the French and UK governments, the response of grassroots organisations and volunteers to the crisis has had a very positive impact on conditions. Volunteers from the UK and around the world are providing clothes, tents, hot meals and English lessons, and in the past few weeks have built a play centre for children, a library and a refugee advice centre (Gentleman, 2015 November 3).

The CalAid initiative calls for taking actions in Lesvos, Eidomeni and Athens as well. It has organized campaigns similar to the ones in the UK in cooperation with other local, national and transnational groups, including "No borders" and "No one is illegal".

Before concluding this section, it is necessary to note that continuity between "old" and "new" social movements should not be underestimated. As in case of labour movements, the so-called "new" social movements try to challenge oppression and inequality arising from the capitalist economy. For instance, green movements cannot be understood without looking into the functioning of neo-liberal capitalist economy. Similarly, the Occupy Street and anti-austerity movements recently emerged in Spain, Greece, Italy or Belgium are against the functioning of market producing inequalities and poverty. Regarding the emergence of anti-austerity movements in Belgium, Italy, Spain and the UK since 2010, Peterson et al. (2015) states that:

Political protest in Europe since 2000 with the emergence of the global justice movement, and even more profoundly since 2010 with the current wave of anti-austerity protests, has taken a decidedly materialistic turn. Or perhaps, contention in Europe never turned away from issues of economic inequality and social justice, rather research on social movements turned more or less a blind eye towards the 'old' 
social movements of class to a one-sided preoccupation with the postmaterialist concerns of the so-called 'new' social movements environmental, feminist, peace, lesbian, gay, bisexual, and transgender movements, etc. Whatever is the case, we can no longer neglect the materialist focus of contemporary protest (p. 2).

This is the case in the refugee rights movements as well. Even though "social movements are not created by a single variable” (Lopes, 2014, p. 2), the "Refugees Welcome" movement and others emerged also as a response to the global inequality producing refugees and immigrants and to the the restrictive migration regime of the global north. As stated eloquently by Nyers and Rygiel (2012) "restrictions on mobility are generating not only new forms of inequality and social exclusion, but also new forms of political activism.” It is further noted that for many refugee rights movements and no border activists, "border controls are fundamentally akin to a politics of apartheid concerned with preserving the wealth and resources of the north from those displaced from the south after years of (neo)colonial practices have stripped these lands of their resources” (Rygiel, 2011, p. 3). In this context, it is also fundamental to take into account the continuity between NSMs and "conventional" movements in terms of sources and underlying reasons paving way for their collective action.

\section{Conclusion}

This study seeks to explore the dynamics of new social movements with a special emphasis on the "Refugees Welcome UK" in the light of the so-called Syrian refugee crisis. Drawing on the premises of NSMs paradigm, the study addresses the dynamics of this movement under five headings including its demands and objectives, social base, organizational structure, mobilization strategies and medium of action and social location. The analysis demonstrates that the "Refugees Welcome" movement meets all the elements characterizing the NSMs. Yet, it is also contended that the source of its collective action, namely global inequality, represents continuity with the "conventional" movements.

To conclude, the "Refugees Welcome" and similar movements try to challenge and transform states' policies and to mobilize people in support of refugees. As the "Refugees Welcome" movement is a considerably new movement set in September 2015, it is difficult, for now, to assess the impact of the movement on the state policies and public. However, it is argued that the movement has already achieved some early success persuading the government to accept more refugees for resettlement. For example, the movement recently expressed that:

We've achieved a number of crucial successes in recent weeks. The \#1000b4Xmas campaign saw our local groups hold 12 local actions, 
including vigils and marches, on local councils. CitizensUK then held an action in Westminster with 890 people from our member organisations and beyond calling for an increase in the rate of resettlement. Finally, we worked with Anglican bishops to draft a letter to PM Cameron bearing 84 of their signatures and calling for the UK to take more refugees. Six days later, David Cameron adopted our target of 1000 refugees resettled before Christmas and national government is working very hard to reach this target in time. It's vital that we build on the momentum of these successes to secure further policy reforms which are still sorely needed (Refugees Welcome, 2015).

On the other hand, as the Marxist critique suggests, it is still not clear whether these NSMs following a reformist project would offer a sustainable solution to the refugee crisis in the face of security oriented and discriminatory refugee regime of the global north. To answer this question, it is necessary to conduct more research focusing on long-term developments in this field.

\section{References:}

Aljazeera (2015, November 2). UN: Record 218,000 refugees arrive in Europe in October. Retrieved from: http://www.aljazeera.com/news/2015/11/record-218000-refugees-arriveeurope-october-151102103029502.html.

Arslan, D. (2015, October 24). Syrian refugee crisis forces closer cooperation between EU-Turkey. Today's Zaman. Retrieved from: http://www.todayszaman.com/diplomacy_syrian-refugee-crisis-forcescloser-cooperation-between-eu-turkey_402296.html.

Balibar, E. (2015). Borderland Europe and the challenge of migration. OpenDemocracy. Retrieved from: https://www.opendemocracy.net/caneurope-make-it/etienne-balibar/borderland-europe-and-challenge-ofmigration.

Bowcott, O. (2015, October 12). Conservative asylum policy on Syria 'too low, too slow, too narrow. The Guardian. Retrieved from: http://www.theguardian.com/uk-news/2015/oct/12/too-low-too-slow-toonarrow-conservatives-asylum-policy-criticised. Carrol W. K. and Ratner, R. S. (1995). Old Unions and New Social Movements. Labour/Le Travail, 35 (Spring), 195-221.

Chrisafis, A. (2015, October 6). Seven Syrian refugees rescued from Calais port. The Guardian. Retrieved from: http://www.theguardian.com/world/2015/oct/06/seven-syrian-refugeesrescued-from-calais-port. 
Feixa, C., Pereira, I. and Juris, J. S. (2009). "Global Citizenship and the 'New, New' social movements: Iberian connections”. Young: Nordic Journal of Youth Research, 17 (4), 421-442.

Gentleman, A. (2015, November 3). Aid workers at Calais refugee camp appeal for right kind of donations. The Guardian. Retrieved from: http://www.theguardian.com/world/2015/nov/03/aid-workers-at-calaisrefugee-camp-make-plea-for-right-kind-of-donations.

Graham-Harrison, E. and Davies, L. (2015 September 12). "Refugees welcome here': UK marchers take to streets with message of support. The Guardian. Retrieved from: http://www.theguardian.com/world/2015/sep/12/refugees-welcome-ukmarchers-un-warns-war-syria-million-displaced.

Gunathilake, L. (n/d). New Social Movements and Effective Mobilization of People. Retrieved from: http://cas.illinoisstate.edu/pol/conferences/2012/3A_Dias.docx. [Accessed 7.11.2015].

Güçtürk, Y. (2014). The Loss of Humanity: The Human Rights Dimension of the Civil War in Syria. SETAV. Retrieved from: http://setav.org/en/theloss-of-humanity-the-human-rights-dimension-of-the-civil-war-insyria/book/16166.

Habermans, J. (1981). New Social Movements. Telos, 49 (Fall), 33-37. Hall, A. and Lichfeld, J. (2015, August 25). Germany opens its gates: Berlin says all Syrian asylum-seekers are welcome to remain, as Britain is urged to make a 'similar statement'. Independent. Retrieved from: http://www.independent.co.uk/news/world/europe/germany-opens-its-gatesberlin-says-all-syrian-asylum-seekers-are-welcome-to-remain-as-britain-is10470062.html.

Hardt, M. and Negri, A. (2001). Empire. Massachusetts: Harvard University Press.

Johnston, H., Laraña, E. and Gusfield, J. (1994). Identities, Grievances, and New Social Movements. In H. Johnston, E. Laraña and J. R. Gusfield (Eds), New Social Movements: From Ideology to Identity, (pp. 3-35). Philadelphia: Temple University Press.

Lise, M. (2013). Does the state turn 'new' social movements into 'old' social movements?. Retrieved from: http://www.angelfire.com/falcon/sociology/socialmovement.pdf.

Lopes, A. R. (2014). The Impact of Social Media on Social Movements: The New Opportunity and Mobilizing Structure. Retrieved from https://www.creighton.edu/fileadmin/user/CCAS/departments/PoliticalScien ce/Journal_of_Political_Research_JPR_/2014_JSP_papers/Lopes_JPR.pdf. Melucci, A. (1980). The New Social Movements: A Theoretical Approach. Social Science Information, 19 (2), 199-226. 
Melucci, A. (1989). Nomads of the Present: Social Movements and Individual Needs in Contemporay Society. Philadelphia: Temple University Press.

Nyers, P. (2015). Migrant Citizenships and Autonomous Mobilities. Migration, Mobility, and Displacement, 1(1), 23-39.

Nyers, P. and Rygiel, K. (Eds.) (2012). Citizenship, Migrant Activism and the Politics of Movement. Oxon: Routledge.

Öğün-Emre, P., Çoban, B. and Şener, G. (2014). Humorous form of protest: Disproportionate use of intelligence in Gezi Park's Resistance. Paper presented at Political Science Conference (Politsci '13), Istanbul, Turkey.

Peterson, A., Wahlström, M. and Wennerhag, M. (2015). European AntiAusterity Protests - Beyond "old" and "new" social movements. Acta Sociologica, 58 (4), 1-18.

Refugees Welcome (2015). Refugees Welcome. Retrieved from: http://www.refugees-welcome.org.uk/.

Rygiel, K. (2011). Bordering solidarities: migrant activism and the politics of movement and camps at Calais. Citizenship Studies, 15 (1), 1-19.

Scott, A. (1990). Ideology and the New Social Movements. London: Unwin Hyman.

Slater, D. (1991). New Social Movements and Old Political Questions: Rethinking State-Society Relations in Latin American Development. International Journal of Political Economy, 21 (1), 32-65.

Spiegel (2015, November 2). Merkel Under Fire as Refugee Crisis Worsens. Retrieved from: http://www.spiegel.de/international/germany/merkel-underfire-as-refugee-crisis-in-germany-worsens-a-1060720.html.

The Telegraph (2015, September 4). Migration crisis: Desperate refugees escape camps and start a 110-mile trek to Austria. Retrieved from:

http://www.telegraph.co.uk/news/worldnews/europe/11843189/EU-refugeecrisis-Migrants-in-Bicske-station-Hungary-siege-continues-overnightlive.html.

Touraine, A. (1981). The Self-production of Society. Chicago: University of Chicago Press. 